\title{
The German Federal Election of 2017: How the Wedge Issue of Refugees and Migration Took the Shine off Chancellor Merkel and Transformed the Party System
}

JÖRG MICHAEL DOSTAL

\begin{abstract}
The 2017 German federal election delivered dramatic electoral decline of the two traditional main parties, the Christian Democrats (CDU/CSU) and the Social Democratic Party (SPD), who had governed Germany in a 'grand coalition' government since 2013. The main reason for this outcome was the decision by Chancellor Angela Merkel to open Germany's borders for refugees and migrants, an unprecedented policy that abandoned border controls and remained in place between September 2015 and March 2016. This article focuses on how the refugee and migration problem subsequently turned into a wedge issue, splitting most German political parties and handing a major election victory to the main critics of Merkel's decision, namely the rightist Alternative for Germany (AfD) and the right-wing liberals of the Free Democratic Party (FDP). Rather than explaining these developments in isolation, the article highlights how past welfare state retrenchment and fear over future economic prosperity make significant groups of the electorate, including former supporters of left-of-centre parties, lose confidence in the ability of the political system to deliver stability and social integration.
\end{abstract}

Keywords: Angela Merkel, Germany, German party system, migration policy, refugee policy, social policy, wedge issue

\section{Introduction: German politics since unification}

EXPLAINING THE CURRENT state of German politics requires a short review of the larger picture. Since the country's reunification in 1990, three Chancellors have held office: Christian Democrat Helmut Kohl until 1998, Social Democrat Gerhard Schröder between 1998 and 2005 and Christian Democrat Angela Merkel since 2005. The period directly after unification gave rise to a shortterm economic boom, during which West German companies gained access to 16 million new East German consumers. This boom, based on the pent-up demand for West German consumer goods in the East, quickly fizzled out. The lasting result of this episode was the near complete disappearance of East German industry followed by a

All German sources translated by the author. rapid rise in East German unemployment to levels that have been high ever since. In order to deal with the social costs of unification, the existing structures of the West German welfare state, such as unemployment and pension insurance, were used to manage the post-unification economic decline in the East. This contributed to the fiscal crisis of the German welfare state, undermining the country's social market economy that had, until then, been based on a consensus model that brought employers, trade unions and the state together in decision-making on social protection issues.

A second major development since unification has been demographic decline. Germany has become a low fertility society with birth rates near the very bottom by global comparison. Policy efforts to make raising children in Germany more attractive have so far had nearly no impact on the low birth rate. 
Post-unification politics has essentially been characterised by three major pathbreaking decisions, in 2003, 2008 and 2015, respectively, each significantly changing the German polity. The first one was welfare state retrenchment during the so-called 'Hartz reforms' of the red-green (SPD and Green party) government of Chancellor Gerhard Schröder that took place from 2003 and was also supported by the then opposition CDU/CSU. The essential feature of this retrenchment was radically to cut entitlements for core workers in the event of unemployment, by introducing time limits on social insurance benefits or by removing social insurance altogether in favour of means-tested welfare payments that were only available after the unemployed had used up nearly all of their personal savings. In parallel, pension levels were also cutagain based on an agreement between SPD and CDU/CSU.

It is hard to overstate how unpopular these reforms were and still are in the context of German politics. They dramatically weakened the SPD, which has since lost more than half of its former electorate. According to one former SPD party chairman, 'proud ship building workers who paid all their life contributions to social insurance are suddenly, at the advanced age of 56, turned into welfare recipients and social outsiders. This they have not forgiven us. ${ }^{1}$ Electoral decline of the SPD aside, the political net result of the Hartz reforms was the rapid expansion of low-wage and non-standard forms of employment in a deregulated labour market, in which the share of the working poor has grown rapidly.

The second major turning point, somehow more difficult to summarise as it is still playing out today, was the reaction of German policy-makers to the global financial crisis starting in 2007 and escalating in 2008. This crisis questioned the survival of the banking system and even of global capitalism, and was 'solved' by the taxpayer 'rescuing' the banks. This move turned the banking crisis into a public budget crisis. In the German context, most people feared that the real economy would be negatively affected by the events in the financial sector and the rapid increase in public deficits. Yet this did not happen. Instead, Germany entered a period of economic recovery that was at least partially based on structural changes, such as the lower external value of the euro that facilitated German exports. Yet some of the rapid adaption to the global crisis was also due to the rediscovery of nearly forgotten German virtues, such as unions and employers in the car industry coming together to save jobs by coordinated cuts in working hours. Another policy instrument, the so-called Abwrackprämie (scrappage allowance), brought the state in to facilitate the purchase of new cars. Yet these developments did not restore earlier neo-corporatist ways of decision making; they amounted to the final hour of glory of the past system.

Soon after, Germany's economic recovery acquired the characteristics of an artificially engineered boom. At the centre of this boom was (and is) the European Central Bank, which, under the leadership of Mario Draghi, has turned towards a zero interest rate policy in order to 'save' the euro. In his famous remark on 26 July 2012, Draghi promised to do 'whatever it takes' to retain the common currency. This real life macroeconomic experiment in 'free money' is the main reason for Germany's current day economics, namely a rapid rise in real estate prices and a stock market boom (no surprise here from a British perspective). The other side of the coin is the slow, but steady decline in the value of money savings, eroded by minimal interest rates that are kept below the rate of inflation. Overall, Germans were, pre-euro, used to a stable currency - a major difference to the Mediterranean capitalisms and the British modelrather than the soft currency policies of the current period that silently redistribute wealth between different asset holders and facilitate speculation in real estate. The net result of these monetary policies has been a split within the bourgeois centre of German politics, between the supporters of Merkel's muddling through and those who demand a return to macroeconomic stability in line with pre-crisis views of what constitutes 'solid' economics.

Third, Chancellor Merkel's decision to open temporarily Germany's borders to refugees and migrants without any border checks, on 4 September 2015, was certainly the most controversial single step of her 
political career and is still contested today. The next section, therefore, discusses the major policy issues that have had decisive influence on the outcome of the German federal election of 2017, in order of their respective significance.

\section{Main issues in the 2017 German federal election}

There exists general agreement in recent opinion polls that the refugee and migration issue is by far the most frequently stated single concern in people's minds when thinking about their election choice. One representative study, allowing multiple responses, suggested that 44 per cent of people interviewed considered the refugee and migration issues significant, while 20 per cent mentioned social injustice and poverty, 14 per cent education and schools, 12 per cent unemployment and labour market issues, and 11 per cent crime levels and law and order. $^{2}$ Another study, conducted slightly earlier and using a similar methodology, produced almost identical results, namely 56 per cent expressed concern over migration and integration issues, 17 per cent highlighted poverty-often with reference to anxiety over future lower pension levels-while 16 per cent each mentioned crime and unemployment, 14 per cent pensions and old-age security and, 12 per cent each, the cost of living and education policies. ${ }^{3}$ One can sum up these findings, in the sense that economic and social issues-promising topics for leftof-centre parties - feature prominently on the public agenda. Nevertheless, all of these issues are still secondary when compared to the refugee and migration problem.

\section{Refugees and migration: the ultimate wedge issue}

It is hardly possible to overstate how refugee and migration issues have, since September 2015, become the ultimate 'wedge' issue of German politics. Yet what actually happened in terms of the German government's policy choices in September 2015 still remains contested today. This lack of clarity starts with the demarcation between the two terms 'refugee' and 'migrant'. In the former case, the German, EU and international legal order suggests that refugee status might be granted to those facing individual persecution in their country of origin due to their race, religion, nationality or political beliefs. In addition, those fleeing armed conflicts, such as the one in Syria, might be granted temporary protective status (subsidiärer Schutz), but not refugee status, until the end of a conflict allows repatriation. There is no initial expectation that the protective status will result in permanent residency in Germany. In the latter case of migration, there is the expectation that newcomers will integrate into German society and the labour market in a way that benefits both sides. In practice, the terms have been used without any clear distinction by politicians and the media, although critics have stressed that such distinctions are crucial in order to provide legitimate and transparent policymaking with regard to the question of who qualifies for temporary or permanent residency in Germany. In order to highlight the unclear demarcation between the two groups of people, the remainder of the article uses both terms.

The supporters of Merkel argue that her policy of 'Grenzöfnung für Flüchtlinge', that is, the 'opening of borders for refugees' (one should note that the German noun for the opening of borders makes Germans remember the opening of the intra-German borders in 1989), was a humanitarian response to an emergency situation, triggered by the Hungarian government's inability to take care of large numbers of refugees congregating in the Hungarian capital of Budapest. According to some observers, this resulted in the 'spontaneous' decision on the part of the refugees to walk to the Austrian and German borders. This refugee movement, it is said, could only have been stopped by violent means, and Merkel decided under the pressure of events to accept the entry of refugees into Germany without any border controls. ${ }^{4}$

Merkel's critics suggest, however, that her policy amounted to 'chaotische und unregulierte Masseneinwanderung' ('chaotic and unregulated mass migration'). They consider the opening of borders to be an irresponsible act from the point of view of the native population. Even moderate critics, who might 
accept that Merkel was under pressure at the moment of taking her initial decision, criticise her for abusing her executive privilege as Chancellor in failing to ask for input from the German parliament or for consultations with other EU member countries. They also raise questions about the unclear legal foundations of Merkel's decision. ${ }^{5}$ Moreover, critics hold that her unwillingness to close the borders for many months after the initial decision - the borders remained open until March 2016 when a 'deal' with Turkey closed down the so-called 'Balkan route'encouraged more and more refugees and migrants to move to Germany. This splitting of the EU over refugee and migration issues - that continues today-has triggered high costs for Germany as a host society or permanent destination for refugees and migrants who turned out to be mostly (approximately 70 per cent) young men from North Africa, the Middle East and other Muslim-majority societies. While Syrians form the largest refugee group, making up around a third of all people applying for asylum in 2015, the majority of those entering Germany had no common country of origin or joint cultural reference point.

Subsequent events, such as the large-scale sexual violence against women in public places in Cologne, Hamburg and some other German cities on New Year's Eve 2015crimes that were initially downplayed by the German police authorities and that ultimately, in summer 2016, were declared to have involved around 1,200 female victims and around 2,000 foreign perpetrators, at least half of them believed to have been recent arrivals-have significantly changed public attitudes towards refugees and migrants. According to Holger Münch, the head of the German Federal Crime Police (BKA), 'there is a connection between the emergence of this phenomenon and the rapid migration in $2015^{\prime} .{ }^{6}$ One year later, the terror attack on the Christmas market in Berlin on 19 December 2016 left twelve people dead and fifty-six people injured-the first Islamist attack on this scale in Germany. The terrorist in question, who was lethally shot four days later by police in Italy, was of Tunisian origin and had entered Germany in June 2015 after a previous four-year jail term in Italy for drug-related offences.
Significantly, the police and public authorities' response to this attack was once again characterised by delays, poor communication with victims' families and even the manipulation of police files to cover up shortcomings in police work. ${ }^{7}$

Here is not the space to review these events further. Decisive in the context of the federal elections is that the topic has not lost its relevance due to policy changes on the part of Chancellor Merkel - changes such as the German government's agreement with Turkey of March 2016 to stop the further entering of refugees and migrants over the so-called 'Balkan route'. (Turkey has since built a wall on the Turkish-Syrian border to, in turn, stop Syrians from entering Turkey).

In fact, the refugee and migration issue continues to split all political camps across multiple dimensions. In order to understand better why the topic has turned into the ultimate wedge issue, a good point of departure is to realise that the actual policy motivation since September 2015 has been inherently ambiguous. On the one hand, it was argued that we (that is, 'the Germans') help refugees because it is the morally right thing to do. Yet, at the same time, it was also suggested that by allowing refugees and migrants into Germany, the Germans were actually helping themselves. Was it not the case, many claimed, that the refugees, being on average young and at the beginning of their working lives, might turn out to be a blessing for the German labour market? Were they not bound to be future contributors to the German pension system? From this second utilitarian point of view, the refugees were expected to be useful for the host society, at least in the medium and long term. Yet the two points of view were in contradiction with each other. The first one was based on pure ethics and demanded the opening of borders to those who were fleeing unacceptable living conditions. This position suggested that establishing clear distinctions between 'political refugees' and 'economic migrants' was difficult or impossible. However, the second point of view was close to neoliberal concepts of what one might term a 'breathing labour market'. This second position is in the German context referred to as the 'Canadian model', that is, the management of migration according to a scoring 
system that selects migrants based on their economic usefulness. ${ }^{8}$ Needless to say, that reality failed to follow either of these two paradigms, thereby leaving observers confused about what was going on.

\section{Four dimensions of the wedge issue}

Looking further at the wedge issue of refugees and migrants, one might highlight at least four politically significant dimensions, namely, (1) a temporal dimension; (2) a media discourse dimension; (3) an ideological dimension; and (4) a psychological dimension. The first two dimensions might be described as communication issues and the latter two as substantive ones. To begin with, the temporal dimension refers to the transition from happiness to fear about the arrival of refugees. Initially, in late 2015, there was euphoria about the idea that Germany could and should help refugees. This turned into a pervasive fear that 'our' country is bound to become the site of major religious and value conflicts, bringing crime, large-scale disorder and, perhaps, the disappearance of German culture as we know it. Thus there was a dramatic overshooting in public debate, from a naïve 'welcome culture' to a deep-seated fear that German society might face existential threats due to its demographic decline when challenged by large cohorts of young migrants.

The temporal overshoot from euphoria to depression was to a large extent driven by the discourse of the legacy media, that is, state-run TV stations and the print media. These media outlets have subsequently been blamed for their one-sided framing of the events that took off following the decision to open Germany's borders in September 2015. Journalists became activists in spreading a welcome culture that originated with Merkel's grand coalition government and civil society associations such as the Christian churches. The strength of this initial welcome culture stemmed from a combination of elite discourse and strong moral conviction on the part of its advocates. Until the puncturing of this phenomenon by the Cologne events, it was very difficult to voice concern over the unregulated movement of people into Germany without being excluded from representation in the mainstream media.
Those who were critical of the ongoing events and expressed fear of the entry of Islamist networks from the war zones in the Middle East and North Africa, and sought controls on what was, according to existing $\mathrm{EU}$ and national legislation, 'illegal migration', were sometimes accused of being xenophobic or racist, but more often they were just ignored. Yet this singlemindedness on the part of the legacy media in spreading the welcome message was far from being universally shared by the general public. In fact, earlier opinion polls deriving from 2014, suggested that a majority of Germans were concerned about migration levels - much lower at the time of these earlier polls-while also believing that the political class ignored such concerns. ${ }^{9}$ In short, there was a split between government and elite discourse on the one side, and a large strand of popular opinion on the other. Because of this genuine split in public attitudes, the online media filled the gap in critical reporting which, in turn, quickly became radicalised. Soon after, offline and online opinion makers started to blame each other for misleading the public for reasons that were morally repugnant.

Perhaps the most significant wedge concerned political ideology. All political parties from left to right experienced divisions over the refugee and migration issue. The most dramatic split appeared among mainstream conservatives, that is, the rank and file of the Christian Democrats. In some respects, these splits since 2015 are comparable with the splits within the SPD electorate back in 2003, which had been produced by the Hartz reforms. What has happened is that the CDU and CSU have lost a large share of their national conservative wings, leaving only the market liberal and Christian social wings and thereby narrowing their electoral appeal significantly. This split within German Christian Democracy has occurred in a silent manner and without any explicit collective withdrawal, although several leading members of the Alternative for Germany (AfD) are sometime CDU members, or draw support from CDU conservatives who have given up their affiliation. For the time being, the AfD has inherited an entire political group alienated from one of Germany's major parties. Their conviction is that Merkel's migration policies question the cultural 
identity of Germany, namely the JudaeoChristian tradition, and open the doors to creeping Islamisation.

One of the two current AfD leaders, Alexander Gauland, spent his previous political life between 1973 and 2013 in the CDU. His long-term friend Erika Steinbach (a retiring former CDU Member of the federal parliament, long-term representative of the national conservatives in the CDU and now former CDU member), suggested in a speech addressing an AfD election rally that Merkel's withdrawal from nuclear energy, announced in reaction to the nuclear disaster in Fukushima in 2011, 'puts forward the Morgenthau plan', namely the idea of the then US Secretary of the Treasury Henry Morgenthau, Jr, who had in the final stages of World War II proposed to deindustrialise Germany in order to turn it into an agricultural society. Yet, her main complaint was the 'Chancellor's decision for the uncontrolled and unlimited acceptance of migrants' and the failure of the public authorities to punish those refugees and migrants who had presented falsified passports to the German authorities. ${ }^{10}$ Without going into further detail, one must stress that the split between the national conservatives, blaming the Chancellor for repeated offences against the legal order, and Merkel's CDU is now too deep to be fixed.

Chancellor Merkel, the Finance Minister Wolfgang Schäuble, and Horst Seehofer, the leader of the Bavarian sister party of the CDU, the CSU, have all tried to turn the refugee and migration related issues into 'normal' policy-making problems. The open border policies were ended in March 2016 with the result that the number of refugees and migrants has declined from its peak in the second half of 2015 and early 2016. Nevertheless, overall levels of migration to Germany have remained high compared to previous years. The promise made by the German government in 2015 to allow the admission of family members of those granted refugee status, such as Syrians, continues to produce anxiety among the German electorate about a 'second wave' of newcomers. In order to calm down such concerns, a bundle of legislative initiatives was passed by the German federal parliament in February 2016. This included not accepting requests for family reunions for two years, which can be seen as an attempt to keep the issue off the agenda during the election season.

Nevertheless, all such efforts at political triangulation and compromise failed. In particular, Chancellor Merkel continued to stress her unwillingness to introduce upper numerical limits on the right to 'political asylum' (a right enshrined in the German Constitution), while not clarifying how this related to the large-scale inflow of migrants who were not suffering from direct political persecution. In the meantime, Schäuble worked behind the scenes in order to make Turkey cooperate in efforts to close the 'Balkan route' for refugees and migrants. In turn, Seehofer stressed his achievement in having the nonEU Balkan states - such as Albania, Kosovo and Montenegro - declared 'safe third states', thereby stopping asylum requests of nationals from these states in Germany and, in particular, in his own federal state of Bavaria. These efforts all failed, however, to reunite the Christian Democrats or to satisfy the national conservatives. In particular, Seehofer's repeated attacks on Merkel in this context, suggesting that 'the Chancellor has according to my conviction decided for the vision of another republic' and stating that 'the population does not want this country to become a different one', underlined that the CSU wanted to be seen as the stronghold of the traditionalists of the centre-right. ${ }^{11}$ Last but not least, Seehofer has repeatedly promised Bavarian voters that the CSU will place upper limits on migration in any agreements over the next coalition government. This underlines that the difference of opinion between Merkel and the CSU over migration remains on the agenda.

These deep divisions have also affected the centre-left parties. The SPD has been least affected since it has mostly followed Merkel's policies, although the former SPD leader Sigmar Gabriel has argued that 'there is a double task of integration concerning those that have newly joined us; but also those that have always lived here'. ${ }^{12}$ In fact, the SPD has not focused on criticising shortcomings of the integration effort during Merkel's last grand coalition government. After all, the SPD shared responsibility for these policy choices. Within the Left party, the 
debate was also kept off the agenda in the current election campaign. However, the former party chairman Oskar Lafontaine had earlier, in February 2017, stated that the call for open borders is a central demand of neoliberalism' pointing out that employers are 'for free migration to attract qualified workers from developing countries in order to use increased migration to increase wage competition'. In addition, Lafontaine stressed that the control of migration levels was the 'foundation of state order', while his wife and co-chair of the Left party, Sahra Wagenknecht, argued that Merkel shared responsibility for the Islamist attack in Berlin due to her 'uncontrolled opening of borders' and earlier cuts in the number of police personnel. $^{13}$

Finally, a fourth dimension of the wedge issue is the psychological aspect. Many observers of the debate see German attitudes with regard to refugees and migrants as deriving from personal negative experiences that came with the loss of control that globalisation has imposed on the sense of historical continuity in a local cultural context. Overall, this line of thinking relates to the long-standing concern in German sociology with the winners and losers of modernisation. According to observers, openness to other cultures and positive expectations with regard to multiculturalism will be more prevalent in periods of relative social peace, while own experiences of economic precariousness and social exclusion-or fear of experiencing them in the future-will make people hostile to further immigration and turn them into cultural protectionists.

In addition, the long-standing experience of German society with low fertility levels produced in many observers a degree of cultural fatalism. Are the Germans not set to disappear from the stage of history? One of the prominent thinkers in this context is Gunnar Heinsohn, a senior German scholar, who has turned the theoretical concept of the 'youth bulge' (the observation that high numbers of unattached young males in highfertility societies might trigger a rise in general insecurity and a tendency toward war) into a general framework for explaining likely future scenarios for European societies. In his thinking, population growth in 'young' African societies must produce conflicts with the 'aged' European societies. The strength of this argument, delivered at the 'meta level' of a cyclical view of history, should not be underestimated as a potential influence on popular attitudes to refugees and migrants. ${ }^{14}$

Another line of thinking, located at the level of individuals, is the suggestion that the 'losers' among the native German population lack the experience of exercising their own agency: 'As more people are disappointed and depressed, as more they feel alienated ... as more radical is their need to develop a strategy of building walls. The threatening world should be pushed back, the relationship with it should be cut.. ${ }^{15}$ Another author claims that the most important political success of the right-wing in 2016 was to place the movement of refugees in the everyday reasoning of large sectors of the population as a metaphor for the general loss of political control. This way, the demand for closed borders becomes a symbol for the restoration of popular sovereignty'. ${ }^{16}$

While this line of psychological reasoning reminds one of efforts of Wilhelm Reich in his Mass Psychology of Fascism ${ }^{17}$ to explain the support for the Nazi movement among working class constituencies as being due to authoritarian socialisation and sexual repression, one must nevertheless highlight blatant shortcomings too. Specifically, it is too easy to claim that the right-wing 'placed' the issue in people's minds as a 'symbol'. Rather, the loss of political control was very real, and people were left alone with their fear that open borders and unchecked entering of people from many parts of the world - the condition on Germany's borders between September 2015 and March 2016were bound to destabilise society to some extent. The symbol for this was, and currently still is, Chancellor Merkel's refusal to place limits on migration. This very refusal must trigger concern in the minds of voters who have experienced Merkel over many years as someone who has always been keen to organise her political agenda by closely following opinion polls. Voters cannot help but notice that Merkel has turned into a person of strong principles on the one issue that, according to all opinion polls, is the lead issue of concern. Why, they ask, has the 
Chancellor started to be principled on an issue that might actually hurt her at the ballot box?

Last, one might also highlight that the principle of 'one citizen-one vote' does not place any limits on the right of depressed people to participate in elections in comparison with those who are more happy. Thus, initial efforts on the part of most of the media to describe the management of refugee and migration issues as successful and to keep silent about crime and disorder-for fear of stigmatising all refugees in the eyes of the German public-have triggered a strong backlash. This has helped the AfD and, to a lesser extent, the liberal FDP, which has also criticised Merkel's open border policies between September 2015 and March 2016. In effect, these two parties have managed to fill the gap in political representation vacated by the other parties.

\section{Beyond the wedge issue: welfare and social policies}

Moving on from the wedge issue of refugees and migration to the other important issues on voters' minds, one enters a more straightforward terrain. As already sketched above, the welfare retrenchment policies of the two main parties in the German party system at the beginning of the twenty-first centuryback then led by the Schröder-SPD and backed up by the CDU/CSU-have undermined the sense of social integration and social peace that had previously characterised the German political model. The across-the-board cuts in welfare state systems in the early 2000s-unemployment insurance, pension replacement rate, occupational sickness insurance and others-have stripped what used to be referred to as the 'Bismarckian welfare state' of its earlier concern with the protection of achieved social status. Observing this development, middle class audiences have started to feel increased anxiety about what would happen to them in the case of job loss and economic downturns.

The clearest example of the relative weakening of German welfare standards has been the decline in projected future pension levels in comparison with wages (the replacement rate). Before the cuts in the pension formula in the early 2000s, average earners with an average record of contributions to pension insurance could count on pension levels that were above the means-tested social assistance level (the means-tested benefit of last resort for poor people). In recent years, this is no longer the case. The main structural reasons for this development are the decline of collective bargaining arrangements that used to limit wage inequalities across sectors, and the parallel growth in low wage and temporary employment. These two long-term developments, in turn reflecting the decline of trade unions and the deregulation of the labour market, have facilitated outsourcing and fragmentation of the labour process, resulting in the growth of new forms of precarious employment. ${ }^{18}$ The grand coalition government of CDU/CSU and SPD, in office since 2013, has failed to control these developments. Instead, their efforts with regard to pension policies have further increased labour market dualism. All recent policy initiatives with regard to pensions have focused on expanding occupational pensions, a system that is not available to workers in small companies and in low wage and precarious employment, and on private voluntary insurance (the socalled 'Riester-Rente', named after a former SPD labour minister, and based on financial products provided by banks and insurance companies in which individual contributions are subsidised by the state). These systems have failed to make up for parallel cuts in entitlements in the public pension system. Many of today's workers know that they have little to expect from the current pension system. $^{19}$

During the election campaign, Merkel duly experienced criticism of her social policy record. One might have expected her challenger from the SPD, Martin Schulz, to lead the charge. Yet the single TV debate between Merkel and Schulz on 3 September 2017 was generally considered to have been boring. One observer summed it up as 'a duet, rather than a duel' consisting of 'lack of actual debate', 'polite exchange of policy ideas' and 'plenty of nodding of heads'. ${ }^{20}$ Yet this was not the case in two other TV debates hosted by the two state TV broadcasters (ARD and ZDF), when the Chancellor faced a live studio audience. These TV 
events underlined the decline of deference on the part of the German public. Merkel unexpectedly faced two rhetorical 'duels': first with a female cleaner close to retirement, who is also a member of the Left party and a trade union representative; and, second, in the other programme, with a young man who is engaged in vocational training to become a hospital nurse. In the former case, the cleaner pointed out that she would retire after 40 years' work with a pension that was below the level of social assistance, excluding her from any form of future participation in public life because of old-age poverty. She described the German pension system as inadequate when compared with the Austrian system in which she would receive a much higher pension with the same employment record. In the latter case, the nurse in training attacked the poor conditions faced by hospital patients as inhumane owing to extreme levels of understaffing in hospital wards. Based on his own experiences, he suggested that basic human rights were ignored in the case of the weak and vulnerable, and that the low wages paid to hospital care workers would result in future deterioration due to the unpopularity of a line of work that was treated as a pure cost factor that needed to be minimised.

In both cases, Merkel was hard pressed to issue a response. In the first case, she offered little more than the statement that 'I can understand you well'. In the latter case, she suggested, probably against her own intentions, that the best way to improve terms and conditions of care workers in hospitals was collective action. According to Merkel 'if necessary, we might have to take in nurses from European countries, for example, additionally ... but in the tariff negotiations it must be paid better too'. She suggested that the male nurse should 'see what your colleagues who have become mechatronic technicians earn and what you do not earn, then we get some more pressure into it'. These statements could be read as Merkel's endorsement of membership in trade unions and a solidaristic wage policy, although they were probably just issued in the heat of the moment. In any case, the two questioners gained immediate popularity on the internet for their refusal to let Merkel get away with her muddling through statements. The exchanges - another member of the audience interrupted the Chancellor stating that it is a joke what you are telling here'-were quickly watched by hundreds of thousands of people on the internet. One could not help but think that citizens challenged the Chancellor in a much more effective manner than Martin Schulz, her official opponent.

Other potentially significant topics of the election campaign, such as Merkel's announcement that Germany would expand its defence expenditure to 2 per cent of GDP in line with NATO plans endorsed by US President Donald Trump - in effect a doubling of the current level-only made shortterm appearances in the election debates. Here, SPD candidate Schulz made an effort to challenge Merkel because of the unpopularity of these ideas with the general public. In fact, most Germans do not aspire to defence budgets at the level of France or Britain and do not support further German military entanglements overseas. Yet, the legacy media did not give him much space on this topic, and Schulz subsequently failed to take control of this or any other issues that could have served as a tool to challenge Merkel. Another potentially significant issue, the expansion of the digital economy, was in the meantime successfully appropriated by the liberals of the FDP, not least because it was not contested by the other parties. Other major issues, such as the future of the European Union and/or the euro, were noticeable by their absence from the debate. In the end, Merkel had decided to avoid political commitments of any kind before election day, thereby leaving the voter only a choice of placing confidence in her personal leadership or rejecting her.

\section{Party campaigning in the 2017 federal election}

This section briefly sketches the parties' campaign efforts in order of their share of the vote in the 2017 election. To begin with the CDU: the party led a campaign focusing on what was held to be a strong economic record, and on Merkel as the Chancellor. The major campaign slogan of the CDU was 'For a Germany in which we live well and feel good' while another slogan read 'For a 
strong economy with safe jobs'. This was criticised for its lack of substance, but in fact did not differ much from earlier CDU campaigns that had also been short on specific policies in order to put forward a 'catch-all' message. As in the past, the CDU made efforts at grassroots mobilisation by organising street rallies with the Chancellor. But these efforts backfired: the number of CDU party supporters in the streets was modest, while they attracted large crowds of protesters, especially in East Germany. They were in effect turned into informal counter rallies of AfD supporters chanting that Merkel should 'get lost'. Merkel tried to stick it out, perhaps wishing for solidarity with her as a person among the broader electorate, which failed to materialise.

The CSU had earlier disagreed with the CDU regarding Merkel's position on refugees and migrants, demanding an official upper limit for annual migration in order to avoid the appearance of 'parallel societies' in Germany. This demand was put forward in a 'Bavaria Plan', an alternative party manifesto of the CSU that differed from the one issued by the CDU, which underlined that the CSU feared losing voters to the AfD. When Merkel appeared at the final campaign rally of the CSU on the Friday before election day in Bavaria's capital Munich, she faced two kinds of crowds, namely the party faithful placed in a gated-off section of the meeting space that was only partially filled, while the rest of the space further away from her was filled with protesters, many of them AfD supporters, trying to drown her out with whistles. In this situation, one could not help wondering whether the CSU leadership felt that Merkel was receiving the negative feedback she deserved.

The SPD election campaign was a fullscale failure, as was Martin Schulz as a candidate. While Schulz had initially created a wave of enthusiasm within the party and in the media due to his talk of social justice and solidarity at the beginning of 2017, this excitement disappeared in the months before the election. Schulz's major mistake was to avoid any clear positioning. In particular, he failed to clarify what his agenda of social justice was supposed to be based on and to state clearly what he wanted to do. His campaign moved from mistake to mistake. The decision to have the unpopular former Chancellor Schröder give a speech at the SPD election conference immediately raised the question of whether Schulz differed substantially from this predecessor. Schulz failed to attack Merkel in any sustained manner. When facing her during their single joint TV debate, he suggested that Germany should exercise more pressure to have eastern European states accept more refugees, instead of highlighting the shortcomings in the management of migration in Germany and of the many unsolved social problems related to it. Moreover, he called voters of the AfD 'a shame for our country' which came across as arrogant, especially as former SPD voters turned out to be the third largest group among new AfD voters in 2017.

Overall, the SPD is today little more than a party of 'professional politicians'. It no longer enjoys the support of any particular sociological category of people, with the partial exception of public sector employees and pensioners. The party has little life left in it, and there is no Corbyn-like figure waiting in the wings either. All SPD candidates for chancellor in recent times (Frank Steinmeier in 2009, Peer Steinbrück in 2013 and now Schulz) belong to the right-wing of the party, while the left-wing has either dissolved or entered the Left party. When Schulz announced in the night after the election his firm decision to have the SPD enter the opposition benches rather than accepting the offer of talks with Merkel to form another grand coalition, he did so out of desperation about the lowest ever SPD election result in the history of post-war Germany.

As for the AfD, the party consists essentially of two wings: the national conservatives led by Alexander Gauland and the neoliberals led by Alice Weidel, the two cochairs. Gauland was a representative of the right wing of the CDU for four decades before joining the AfD in 2013, while Weidel, an economist, has a political past as member of the Friedrich A. von Hayek Society, a cadre group of market radicals in which she used to rub shoulders with the current FDP leader and various business representatives. ${ }^{21}$ Both AfD wings have come together based on their criticism of the refugee and migration policies of the Merkel government. The conservative wing places its emphasis 
on protecting German cultural identity, while the neoliberals suggest that refugees and migrants are mostly an economic burden placed on the German tax payer.

The AfD has focused on the wedge issue of refugees and migrants in order to target a number of different social groups with contradictory social interests. These target groups are, according to an internal party document, as follows: (1) those opposing the 'rescue of the euro' and the 'European super state'; (2) bourgeois voters with liberal and conservative orientations opposing further migration; (3) protest voters in general and those opposed to 'political correctness'; (4) former non-voters; (5) the socially disadvantaged and those in declining urban areas that support 'order, safety and patriotism' and feel themselves to be 'losers of globalisation', including 'workers and the unemployed'. ${ }^{22}$ One can conclude from the 2017 election result that the AfD has managed successfully to appeal to each of these groups - and in particular to former non-voters and socially disadvantaged groups. In East Germany, the AfD has become the second strongest party and in the eastern federal state of Saxony, the party overtook the CDU to become the strongest party. Thus, the AfD has turned itself in the eastern parts of Germany into what one might describe as a 'people's party' in the sense in which this word has been used in German political science, namely it has gained votes from all sections of society.

Turning to the pro-business liberals of the FDP, the party focused in its campaign on three things, namely: its young and 'charismatic' party leader Christian Lindner; the criticism of Merkel's immigration policies as economically dangerous and possibly illegal; and on 'digitalisation' as a topic defining the economic future of Germany. The FDP applied similar rhetoric to the AfD as regards the 'failed' migration policies of Merkel. Yet as a market-liberal party, the FDP still stressed that migration into the German labour market could be a good thing if regulated by a 'modern' migration law. This implies the 'Canadian model' of selecting migrants according to a scoring system governed by their relative economic utility as judged from the point of view of employers.
The Left party consists of two wings with regard to the refugee and migration issue. The first one could be termed 'radical cosmopolitan' and the second one 'welfare-state realist'. The former group is made up of supporters of 'world socialism in a single country', since they reject drawing distinctions between 'political' refugees and 'economic migrants' because of humanitarian concerns implied in the demand for 'open borders'. The latter group of 'state socialists', on the other hand, stresses that open borders produce increased competition for limited resources of the German welfare state and are therefore utopian. The two wings of the party agreed to disagree on these points, putting forward their positions at the beginning of 2017 and then dropping the issue until election day in order to allow the party to unify in a campaign that focused almost exclusively on welfare policy issues.

The election results for the Left party were mixed. While the party gained additional votes across the former West Germany, it suffered major losses in former East Germany, where the AfD overtook the Left in all federal states, leaving them in the third place behind CDU and AfD. Among the unemployed and blue collar employees, electoral support for the Left fell from 23 and 12 per cent in 2013 to 11 and 10 per cent respectively in 2017. Writing after the election, Lafontaine suggested that it was wrong to place the burdens of migration such as 'increased competition in the low wage sector, rising rents ... growing difficulties in schools with a rising share of pupils lacking German language skills on those that are already losers with regard to income and wealth'. He also stressed that 'experience in Europe teaches: once those people feel no longer represented by left or social democratic parties, they increasingly vote for right-wing parties'.23

Last, the Green party has over the years turned into a new middle class party of the economically well-off with a 'post-materialist' approach to policy-making. The party has mostly rejected placing upper limits on migration. Instead, the focus of the election campaign was placed on climate change and efforts to turn away from a carbon economy. Since the other parties had largely vacated environmental issues, the Greens managed 
to achieve election results that surpassed expectations. The Greens are now in a strong position to enter a future government, although without any clear policy-making agenda.

\section{Conclusion: the crisis behind the crisis of the party system}

The result of the German federal election of 2017 raised many questions about the future of German politics. This conclusion briefly reviews the election results and speculates how the broader picture of neoliberal capitalism and European and global crisis might affect the future behaviour of the partypolitical actors in Germany. The right-wing AfD is the big winner of the 2017 election. The party managed to gain around 1.2 million votes from former non-voters and 1 million from former CDU/CSU voters, but also 470,000 and 400,000 from former SPD and Left party voters, respectively. The FDP as the second winner of this election gained nearly 1.4 million votes from the CDU/CSU and served as the party-political option for those who wanted to put pressure on Merkel without voting for the AfD. ${ }^{24}$ The overall picture is the transition to a more polarised party system with AfD and FDP as newcomers in parliament.

The formation of a coalition government might be very difficult to achieve. The two traditional major parties, CDU/CSU and SPD, jointly received only 53.4 per cent of the overall vote, their lowest ever result in German federal elections. Although the current grand coalition government would technically hold just enough votes in parliament to keep going, this option appears a selfdefeating strategy, especially for the SPD. At time of writing (2 October 2017), the most likely option is assumed to be a so-called 'Jamaica coalition' of CDU/CSU, FDP and Greens. (The respective party colours black, yellow and green make up the Jamaican flag.) The major problem of forming a 'Jamaica coalition' is that the leaders of the four necessary party-political components advance opposing views with regard to the wedge issue of refugees and migrants. The CSU and the FDP have both been highly critical of Merkel's migration policies, while the Greens are mostly committed to a pro- immigration platform and have suggested founding a 'super ministry' for integration policies. There appears to be plenty of reason for the four parties to think twice about joining a 'Jamaica' coalition government if the price would be to disappoint their respective core constituencies. This is particularly the case for the Bavarian CSU, which faces regional elections in 2018 and has already stated that the party will not join a new government without clear agreements on future migration limits.

Moving on from these mostly managerial issues to the larger picture, one needs to stress that refugee and migration issues dominated the 2017 federal elections for two main reasons. First, the entire episode of Germany's 'open borders' between September 2015 and March 2016 was unprecedented in its scope and surprised the political actors. Second, the refugee and migration crisis occurred at a moment in time when there were already other unprecedented problems crowding the agenda, namely, that neoliberal capitalism has, since the global crisis in 2008, run on a policy of zero interest rates. Such experimental macroeconomic policies have made the rich richer while those who placed their trust in a welfare state that continues to experience permanent austerity have lost out. Who is ultimately going to pay the price for these policies is still unclear, and people have good reason to worry about limited resources.

Thus, the forming of the next German government will have to be pursued in a difficult environment. The elections have demonstrated that Germany is divided across multiple dimensions: social and regional divisions have spilled over into the political system. In particular, the cuts in welfare state entitlements and standards in the early twenty-first century have created a precarious class of working poor that is permanently excluded from participating in the economic prosperity elsewhere. Moreover, social and cultural divisions between West and East continue to be significant nearly three decades after unification. The 2017 election has highlighted the fact that the party system is now increasingly regionally structured. While the Christian Democrats have maintained some nation-wide threshold of support, the Social Democrats have 
declined to a North West German party with much lower levels of support elsewhere. Conversely, the AfD has gained strong support in East Germany and the South while the two smaller parties that would be significant to form a 'Jamaica coalition', namely the FDP and the Greens, are strong in the former West Germany and weak in the former East Germany. In summary, the inability of the political system to deliver stability and social integration is reflected in the sheer difficulty of forming a government. In this environment, the wedge issue of refugees and migrants could always re-enter the agenda, questioning the stability of any future coalition government.

\section{Notes}

1 B. Engholm interview, 'Heute fehlt es an Visionären', Heilbronner Stimme, 11 August 2017; http://www.stimme.de/themen/wahle n/btw17/texte/Heute-fehlt-es-an-Visionaeren; art140673,3895167 (accessed 2 October 2017).

2 ARD-DeutschlandTREND, 'Wichtigste politische Probleme in Deutschland', July 2017; https:// www.infratest-dimap.de/umfragen-analysen/ bundesweit/ard-deutschlandtrend/2017/juli/ (accessed 2 October 2017).

3 'Pressemitteilung: Zuwanderung verliert für Deutsche an Brisanz. Ergebnisse der "Challenges of Nations 2017" des GfK Vereins', Nuremberg: Gesellschaft für Konsum-, Marktund Absatzforschung, 25 August 2017; http:// www.gfk-verein.org/presse/zuwanderung-ve rliert-fuer-deutsche-brisanz (accessed 2 October 2017).

4 G. Blume et al., 'Grenzöffnung für Flüchtlinge: Was geschah wirklich?', Die Zeit, 22 August 2016; http://www.zeit.de/2016/35/grenzo effnung-fluechtlinge-september-2015-wochenen de-angela-merkel-ungarn-oesterreich/komplet tansicht (accessed 2 October 2017).

5 For legal issues, see in particular Deutscher Bundestag, Wissenschaftliche Dienste, 'Ausarbeitung Einreiseverweigerung und Einreisegestattung nach $\S 18$ Asylgesetz', WD3-3000-109/ 17, 24 May 2017, pp. 7, 9-11; https://www.b undestag.de/blob/514854/0bdb98e0e61680672e 965faad3498e93/wd-3-109-17-pdf-data.pdf (accessed 2 October 2017).

6 G. Mascolo, B. von der Heide, '1200 Frauen wurden Opfer von Silvester-Gewalt', Süddeutsche Zeitung, 10 July 2016; http://www.sueddeutsc he.de/politik/uebergriffe-in-koeln-frauen-wurde n-opfer-von-silvester-gewalt-1.3072064. See also R. Noack, 'Why it took half a year for the full extent of the New Year's Eve assaults in Germany to be known', Washington Post, 11 July 2016; https://www.washingtonpost.com/ne ws/worldviews/wp/2016/07/11/why-it-tookhalf-a-year-for-the-full-extent-of-the-new-yearseve-assaults-in-germany-to-be-known/?tid=a_in 1\&utm_term=.ae1ef594e0eb (accessed 2 October 2017).

7 'Terror am Breitscheidplatz. Wie planlos agierte die Polizei nach dem Anschlag?', Berliner Zeitung, 15 September 2017; http:// www.berliner-zeitung.de/berlin/terror-am-bre itscheidplatz-wie-planlos-agierte-die-polizei-na ch-dem-anschlag-28419362 (accessed 2 October 2017).

8 A clear statement of market-liberal principles in the context of migration is put forward by R. Springer, Spurwechsel. Wie Flüchtlingspolitik wirklich gelingt, München, Finanzbuchverlag, 2017. Based on his participant observation as civil society assistant to refugees, Springer convincingly describes the shortcomings of the current German asylum bureaucracy. Yet his suggested solution, namely a new administrative system that would exclude refugees from access to the German welfare state and instead would introduce 'integration credits' demanding migrants to quickly enter employment to settle their 'debt' with the German state, appears to amount to a kind of 'refugee workfare'. Implicitly, the author wishes to limit migration to Germany to the able-bodied, therefore coming out firmly in favour of the utilitarian side of the argument.

9 M. Haller, Die 'Flüchtlingskrise' in den Medien. Tagesaktueller Journalismus zwischen Meinung und Information, Frankfurt am Main, Otto Brenner Stiftung, 9 June 2017; https://www.ottobrenner-stiftung.de/fileadmin/user_data/stiftu ng/Aktuelles/AH93/AH_93_Haller_Web.pdf (accessed 2 October 2017).

10 'Merkel-CDU führt Morgenthauplan durchGrandiose Rede von Erika Steinbach', Youtube portal titled 'Freie Propaganda', 14 September 2017; https://www.youtube.com/watch?v=6r ly1IvmmSY (accessed 2 October 2017). In her speech, Steinbach frequently quotes older CDU election manifestos on the need to control migration as evidence for Merkel's offence against basic values of the 'old' CDU.

11 See R. Alexander, Die Getriebenen. Merkel und die Flüchtlingspolitik: Report aus dem Inneren der Macht, 2nd ed., Berlin, Siedler, 2017, pp. 141, 150, 159, 163.

12 'Gabriel attackiert die Union: "Niemand soll wegen der Flüchtlinge vergessen werden"', Frankfurter Allgemeine Zeitung, 18 September 2017; http://www.faz.net/aktuell/politik/bun destagswahl/sigmar-gabriel-attackiert-union-we 
gen-fluechtlingskrise-15204371.html (accessed 2 October 2017).

13 'Die Linke: Oskar Lafontaine fordert konsequentere Abschiebungen', Zeit Online, 8 February 2017; http://www.zeit.de/politik/deutsc hland/2017-02/oskar-lafontaine-linke-abschieb ungen-fluechtlinge-afd (accessed 2 October 2017). For Wagenknecht, compare further online references available in the stated source.

14 Heinsohn sums up his thinking, linking high birth rates and armed conflict in a 'war index', in a lecture titled 'Menschliches Ma $\beta$ für die Kriegsbereitschaft', which was delivered on the occasion of the 70th birthday of philosopher Peter Sloterdijk on 26 June 2017 at the Karlsruhe-based 'Zentrum für Kunst und Medien'; http:/ / zkm.de/media/video/gunnar-heinsohnvon-morgenroeten-die-noch-nicht-geleuchtet-hab en (accessed 2 October 2017).

15 H. Rosa, 'Anverwandlung statt Versteinerung. Zwei Antworten auf die "Flüchtlingskrise", Mittelweg 36, vol. 26, no. 2, 2017, pp. 27-37.

16 B. Opratko, 'Rechtspopulismus als Krisenbearbeitung. Anmerkungen zum Aufstieg von AfD und FPÖ', Prokla, vol. 47, no. 186, 2017, pp. 123-36.

17 W. Reich, Mass Psychology of Fascism, New York, Farrar, Straus and Giroux, 1933.

18 J. Boewe, 'Stupid Work 2.0', 20 December 2014, Lunapark21: Zeitschrift zur Kritik der politischen Ökonomie, Heft 28; http://www.lunapark21.ne t/stupid-work-2-0/ (accessed 2 October 2017).

19 H. Reiners, 'Armutsproduktion mit System', 15 September 2017; https://makroskop.eu/2017/ 09/armutsproduktion-mit-system/ (accessed 2 October 2017).

20 C. F. Schuetze, 'Why a challenger to Merkel faltered after a strong start', New York Times, 23-24 September 2017, p. 4. See also S. Winterbauer, 'Mutti, Martin und die Mutlosen: Warum die Sender schuld an der Langeweile des TV-Duells sind', 4 September 2017; http:/ / www.absatzwirtschaft.de/mutti-martin-und-diemutlosen-warum-die-sender-schuld-an-der-la ngeweile-des-tv-duells-sind-113679/ (accessed 2 October 2017).

21 K. Riedel and S. Pittelkow, 'Die HayekGesellschaft-Mistbeet der AfD'?', Süddeutsche Zeitung, 14 July 2017; http://www.sueddeutsc he.de/wirtschaft/hayek-gesellschaft-mistbeet-de r-afd-1.3589049 (accessed 2 October 2017).

22 AfD-Manifest 2017. Die Strategie der AfD für das Wahljahr 2017, 22 December 2016; https:/ /www.scribd.com/document/338294054/ AfD-Strategie-2017 (accessed 2 October 2017).

23 O. Lafontaine, 'Die Linke und die soziale Gerechtigkeit', 26 September 2017, Facebook page (a)oskarlafontaine; https://www.facebook.com/ oskarlafontaine/posts / 1552437538151041 (accessed 2 October 2017).

24 T. Steppat, 'Merkel und die Koalition der Zufriedenen', Frankfurter Allgemeine Zeitung, 25 September 2017; http://www.faz.net/ak tuell/politik/bundestagswahl/f-a-z-wahlanaly se-merkel-und-die-koalition-der-zufriedenen-15 206260.html (accessed 2 October 2017). 